\title{
Mineral Phase Crystallization Sequence of Delta Steel Company (DSC), Ovwian-Aladja, Western Niger Delta Steelmaking Slag for Use as Material in Industry
}

\author{
Wessey Napoleon Afolabi \\ Department of Geology, Faculty of Science, Niger Delta University, Amassoma, Nigeria
}

Email address:

napwessey@yahoo.com

To cite this article:

Wessey Napoleon Afolabi. Mineral Phase Crystallization Sequence of Delta Steel Company (DSC), Ovwian-Aladja, Western Niger Delta Steelmaking Slag for Use as Material in Industry. International Journal of Materials Science and Applications.

Vol. 6, No. 2, 2017, pp. 99-107. doi: 10.11648/j.ijmsa.20170602.16

Received: January 5, 2017; Accepted: January 31, 2017; Published: March 7, 2017

\begin{abstract}
Slag is a non-metallic by-product obtained in the refining of metals from metallic ores. Slag production at the Delta Steel Company (DSC), Ovwian-Aladja, western Niger Delta, follows the direct iron reduction steelmaking process. Fifteen company slag samples collected were examined by x-ray fluorescence, thin section petrography and electron microprobe analyses to establish the mineralogy and mineral crystallization sequence and thus explain their occurrences. The results show the presence of synthesized silicate minerals of belite, melilite and merwinite; calcium aluminate, wustite, periclase, perovskite and glass in the slag formed at between the temperatures of $1500^{\circ} \mathrm{C}$ and $500^{\circ} \mathrm{C}$. Crystallization sequence is alpha $(\alpha)$ form of belite $\left(1500^{\circ} \mathrm{C}-1420^{\circ} \mathrm{C}\right)$, alpha high $\left(\alpha^{\prime} \mathrm{H}\right)$ belite $\left(1420^{\circ} \mathrm{C}-1160^{\circ} \mathrm{C}\right)$, alpha low $\left(\alpha^{\prime} \mathrm{L}\right)$ belite $\left(1160^{\circ} \mathrm{C}-680^{\circ} \mathrm{C}\right.$, beta $\left(\beta\right.$-) belite $\left(680^{\circ} \mathrm{C}-630^{\circ} \mathrm{C}\right)$, Melilite $\left(1420^{\circ} \mathrm{C}-680^{\circ} \mathrm{C}\right)$, aluminate, merwinite, wustite, periclase, peruvskite and glass $\left(630^{\circ} \mathrm{C}-500^{\circ} \mathrm{C}\right)$ in that order. This study has revealed that in behavior, synthetic minerals also crystallize from high to low temperature forms as is the case with natural minerals formed from silicate magmas. The forming behaviour of these minerals confers on them the important characteristics for industrial use as an industrial mineral compliment to natural materials.
\end{abstract}

Keywords: Steelmaking Slag, Iron, Reduction, Synthesized Silicate Minerals, Crystallization Sequence, Industry

\section{Introduction}

Steel slag is produced by the fluxing of mainly limestone with iron ore to produce steel. Generally, it is a byproduct of steelmaking and steel refining process. Delta Steel Company, (DSC) Ovwian-Aladja, Delta State, Nigeria, steelmaking slag is produced through the direct iron reduction steelmaking process. The process involved the use of Lime from Mfamosing Limestone, Calabar, Cross River State, Nigeria, as a flux and direct reduced iron in pellet form from iron ore from Liberia and local scrap as sources of iron. DSC slag formed between $1500^{\circ} \mathrm{C}$ and $1700^{\circ} \mathrm{C}$ [5] and remained in liquid form. Solid slag containing crystallized minerals may have started cooling from below $1500^{\circ} \mathrm{C}$, ending at $500^{\circ} \mathrm{C}$ [18] [44].

Pioneering works by [1], [6], [8], [14], [15], [19], [21], [22], [30] and others, using microscopy (SEM), X-ray diffraction (XRD) and electron microprobe analyses (EMPA) methods at different times recorded similarities on the composition and transformation of steelmaking slag and Portland cement clinker minerals. Both are synthesized rocks at about the same temperatures and similar elemental substitutions take place within each. They found a list of slag minerals Alite, Belite of different polymorphs, Tricalcium aluminate, Periclase, Free Lime, Tricalcium ferrite and Wustite that occurred in them. The polymorphs of belite $\left(\mathrm{C}_{2} \mathrm{~S}\right)$, include larnite $\left(\beta-\mathrm{Ca}_{2} \mathrm{SiO}_{4}\right)$, bredigite $\left.\alpha-\mathrm{Ca}_{2} \mathrm{SiO}_{4}\right)$, melilite $\left(\mathrm{Ca}_{2} \mathrm{MgSi}_{2} \mathrm{O}_{7}\right)$ and merwinite $\left(\mathrm{Ca}_{3} \mathrm{MgSi}_{2} \mathrm{O}_{8}\right)$. Recent XRD, Scanning Electron Microscopy and Electron Microprobe Analyses (EMPA) studies of steelmaking slags confirm the presence of the crystalline phases of a variety of these minerals. Their presence was due to the chemical composition of steelmaking slag and the slow cooling rate of the slag. Steelmaking slag has been used as material in 
construction, cement, ceramic, glass and the blastfurnace industries based on their chemical and mineralogical compositions [3], [4], [12], [24], [30], [31], [33], [37], [41], [42].

DSC slag, in physical appearance, looked like magma and the cooling was similar to igneous magma. Petrographic, photographic, x-ray diffraction (XRD), scanning electron microscopy (SEM)and electron microprobe analysis (EMPA) studies of samples of the slag identified the occurrence of the minerals belite, calcium aluminate, periclase, peruvskite, periclase, peruvskite, melilite, merwinite, wustite as listed on Table 1 in a crystalization sequence [39]. Belites identified were the five well defined polymorphs, high temperature alpha $(\alpha)$, alpha dash high $\left(\alpha^{\prime} \mathrm{H}\right)$, alpha dash low $\left(\alpha^{\prime} 1\right)$, beta $\left(\beta-C_{2} S\right)$ and gama $\left(\gamma-C_{2} S\right)$ of low temperature [11], [16], [17]. The mineral crytallization sequence of steel slag belite has been studied and reported [20]. This sequence has been used to indicate the general mineral crystallization sequence of DSC slag, limited in literature.

\section{Results}

Test results for the bulk mineralogy and mode of appearance of the slag are presented in Table 1 and Figures 1 to 13 .

Table 1. A list of DSC slag minerals and their chemical formulae.

\begin{tabular}{ll}
\hline Mineral Name & Chemical formulae \\
\hline Belite & $2 \mathrm{CaO} \cdot \mathrm{SiO}_{2}\left(\mathrm{C}_{2} \mathrm{~S}\right)$ \\
Calcium Aluminate & $\mathrm{CaO} \cdot \mathrm{Al}_{2} \mathrm{O}_{3}\left(\mathrm{C}_{3} \mathrm{~A}\right)$ \\
Periclase & $\mathrm{MgO}$ \\
Melilite & $2 \mathrm{CaO} \cdot \mathrm{MgO} \cdot 2 \mathrm{SiO}_{2}$ \\
Merwinite & $3 \mathrm{CaO} \cdot \mathrm{MgO} \cdot 2 \mathrm{SiO}_{2}$ \\
Peruvskite & $\mathrm{CaTiO}$ \\
Wustite & $\mathrm{Fe} 0$ \\
\hline
\end{tabular}

From Table 1, Belite, Calcium Aluminate, Periclase, Melilite, Merwinite, Peruvskite and Wustite were the minerals that crystallized from the cooling of liquid slag.

Figure 1, Figure 2, Figure 3..... Figure 11, show typical back scattered mode Scanning electron microscope (S. E. M) photomicrographs of polished thin sections of DSC slag samples.

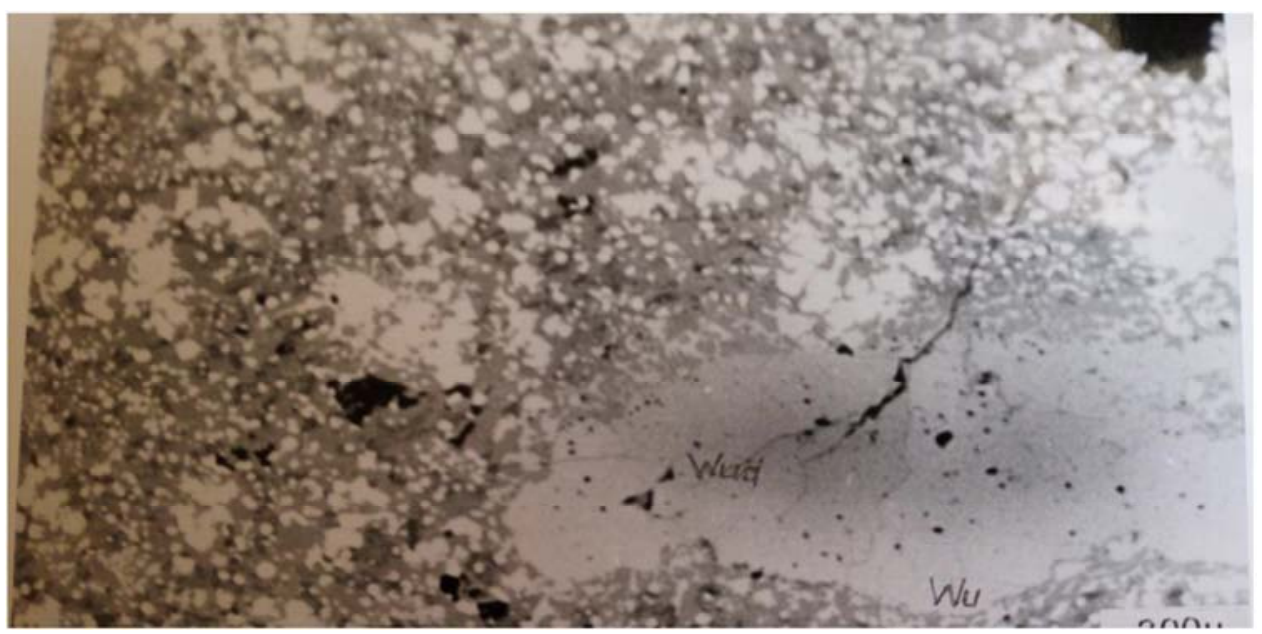

Figure 1. $(200 \mu)$ shows a fractured composite wustite crystal (Wu) with a darker central region resulting from a higher Mg concentration (Wu d) by EMPA analysis results.

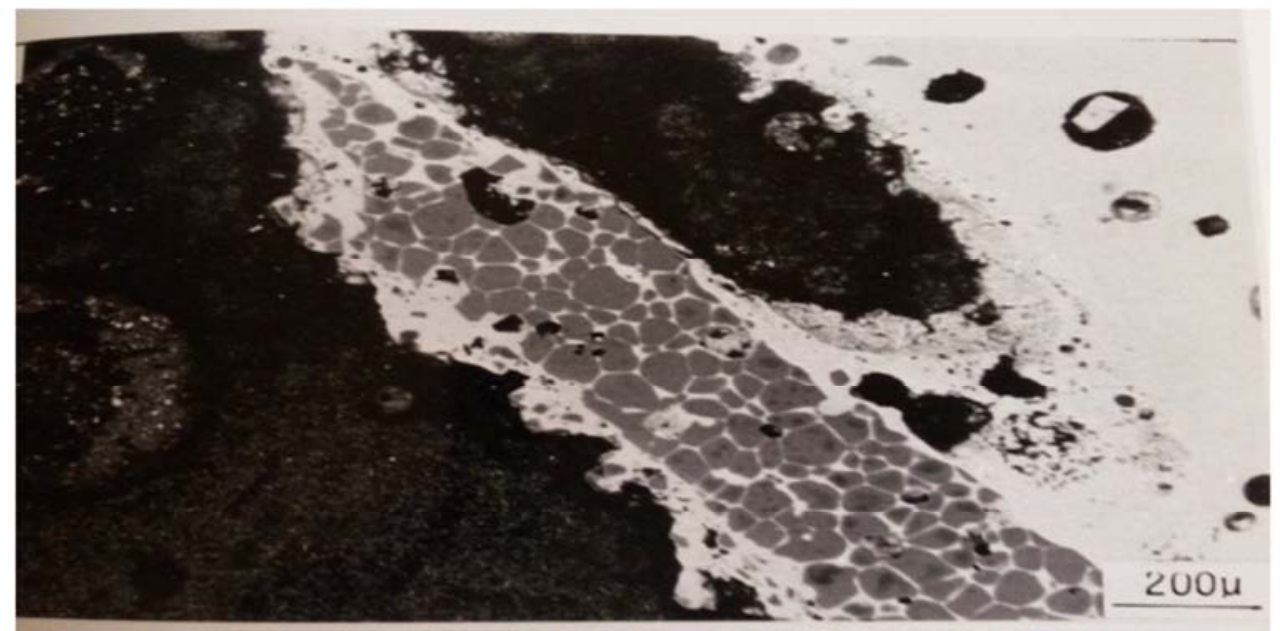

Figure 2. Shows round, rectangular and angular (gray) periclase (MgO) crystals on both a mixed and wustite groundmass but always surrounded by a thin shell of wustite. The wustite had protected the periclase from possible inter-phase or liquid reactions. 


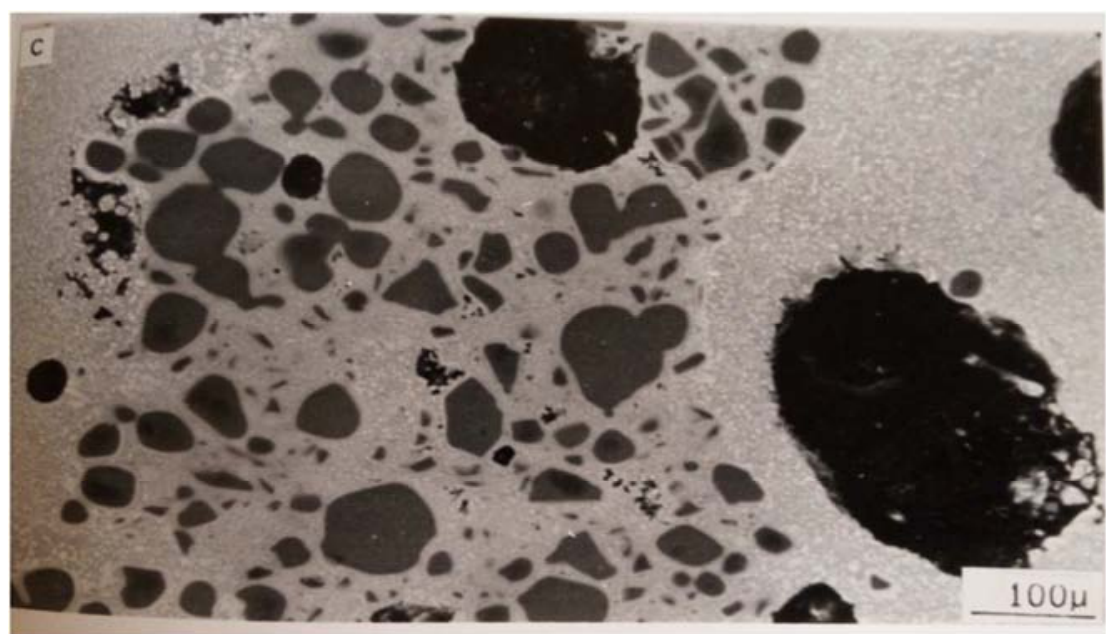

Figure 3. (100 $\mu$ ) Shows periclase shape and roundness and occurrence as in Figure 1.

In all Figure 1, Figure 2 and Figure 3, periclase shape was sometimes obscured by edge rounding and grain coalescence with round blebs in some areas. Rounded blebs on wustite (white) indicated a second stage crystallization. Dendritic wustite were also seen on a mixed ground mass as in Figure 3.

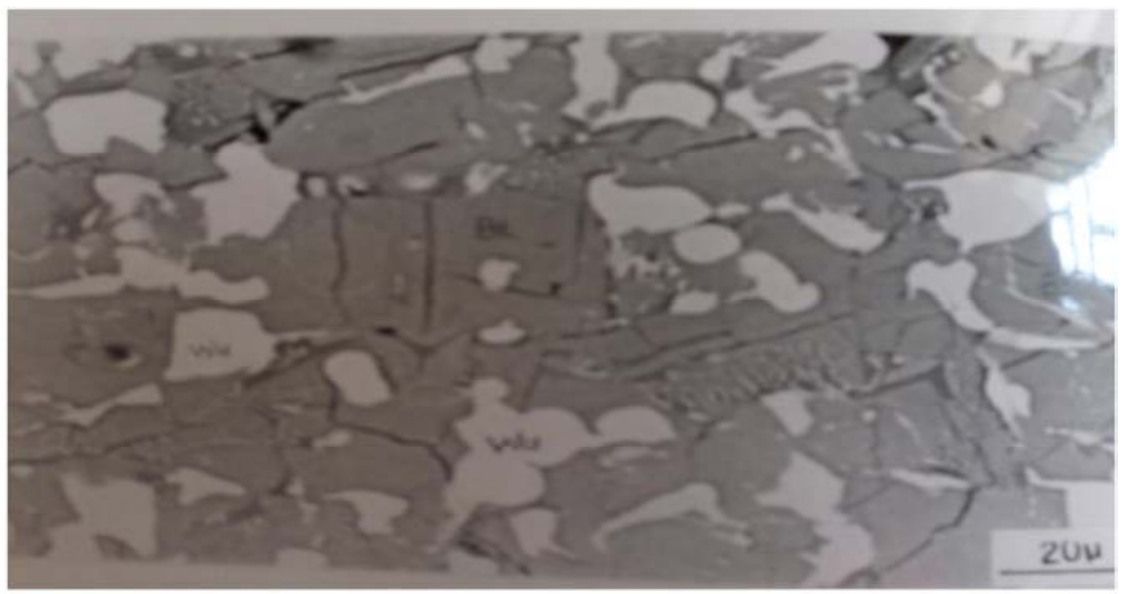

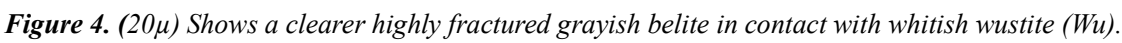

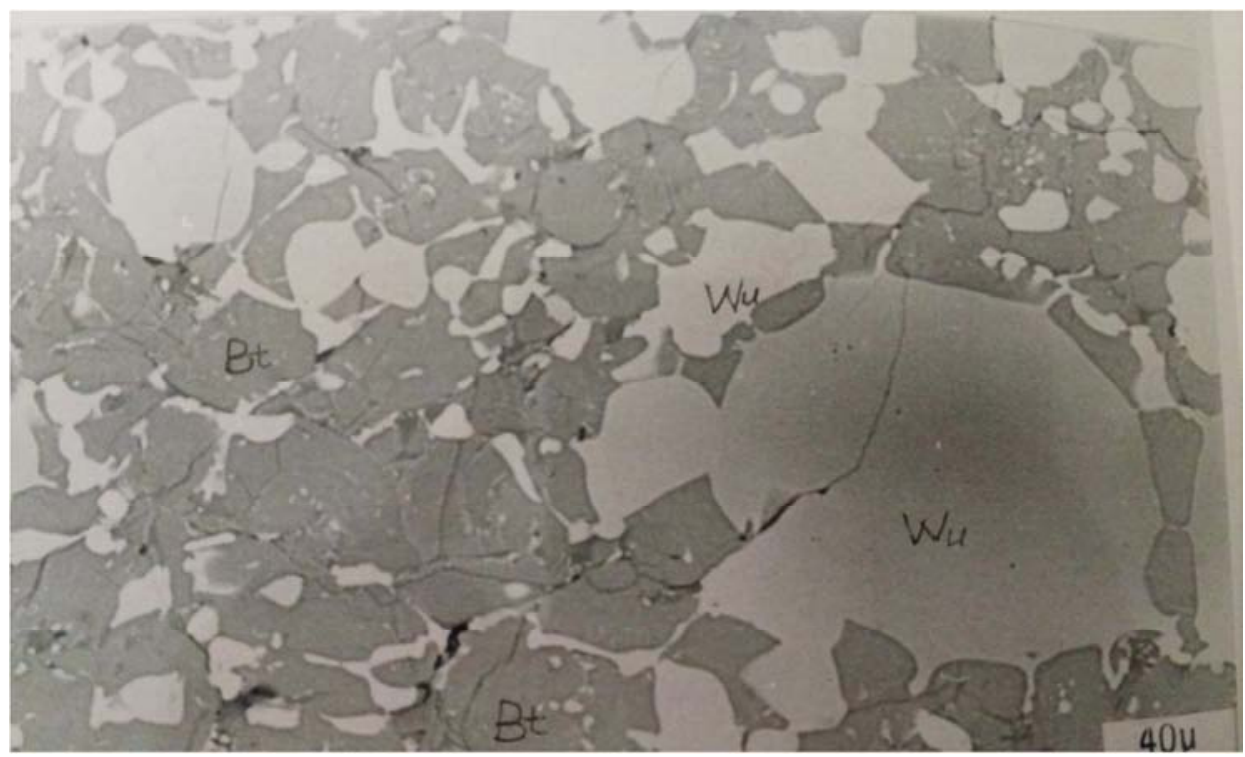

Figure 5. $(40 \mu)$. Belite (Bt- brown) of different shapes and sizes in contact with whitish and grayish wustite (WU) of different shapes and sizes. Tiny grains of wustite (white), enclosed in aluminate-(dark gray). 
Figure 4 and Figure 5 show highly fractured belite (Bt,- grayish colour), the $\alpha$ and $\alpha$ polymorphs unable to transform to the lower temperature forms during faster cooling and in direct contact with wustite- $\mathrm{Wu}$ (white).

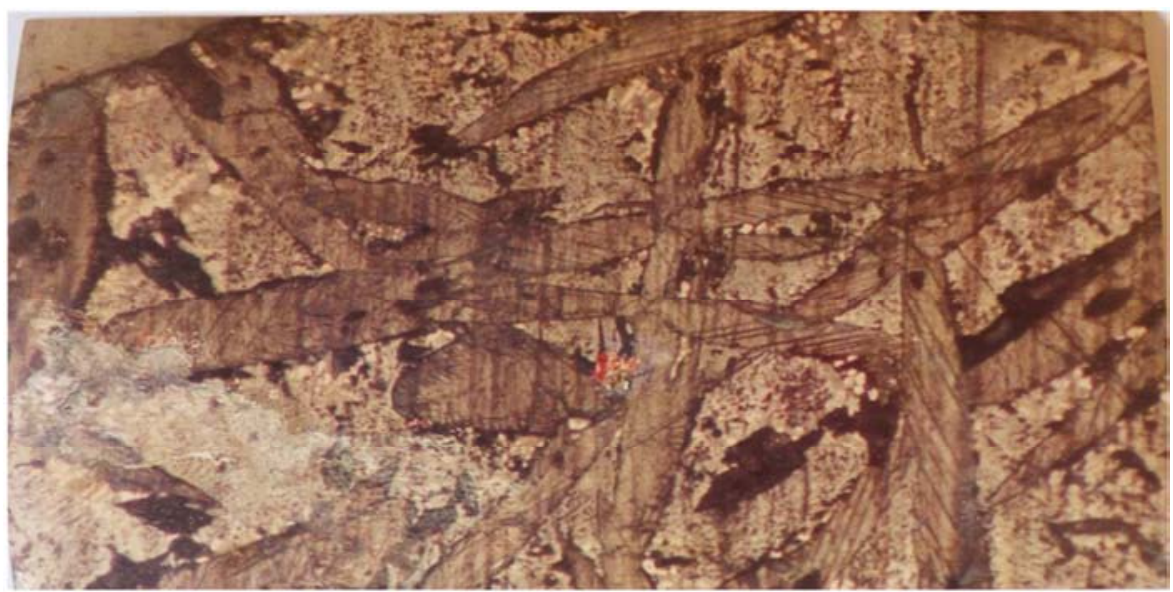

Figure 6. Camera photomicrogram showing light gray and brown belite crystals radiating in different directions from a nucleus or from a larger belite crystal or criss-crossing.

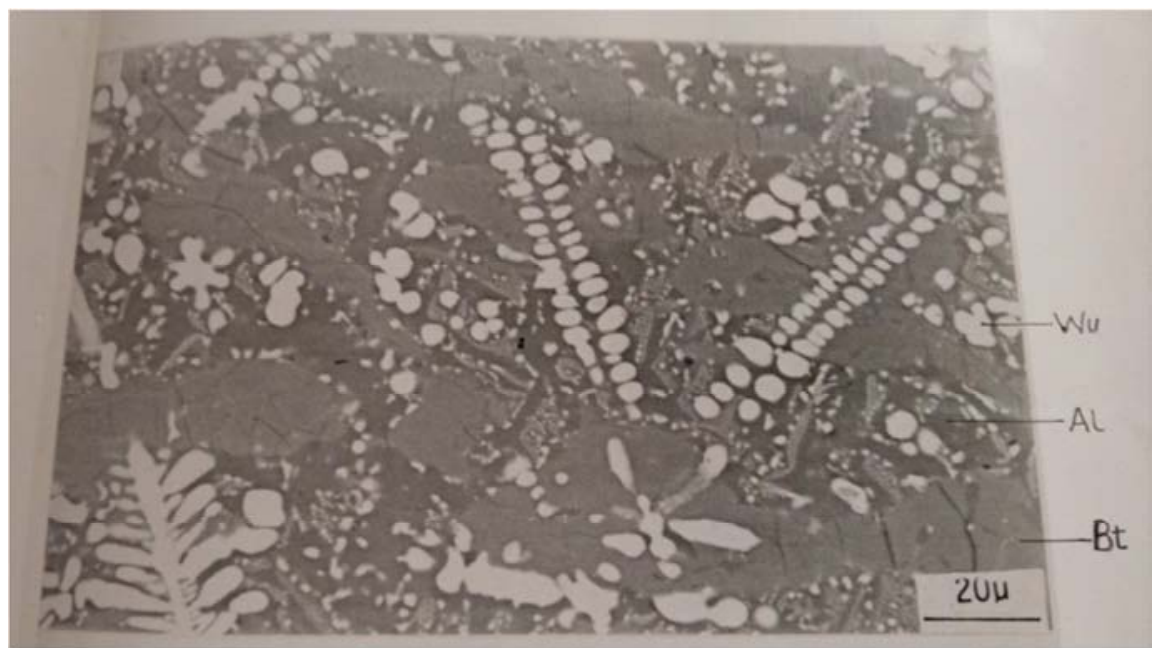

Figure 7. Shows dendritic wustite (Wu-white) in contact with lenticular belite (Bt-light to dark gray) and dark aluminate (Al) of no definite shape. Some wustite grains occur on aluminates.

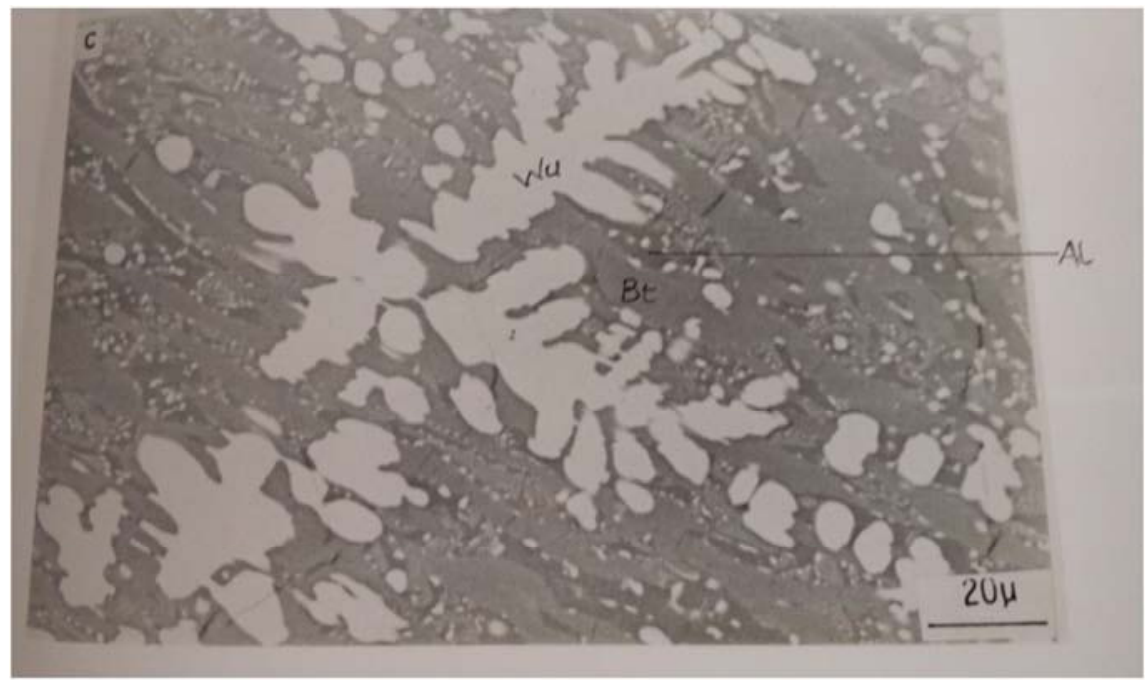

Figure 8. $(20 \mu)$. Shows dendrtic whitish wustites (Wu), lenticular belite (light to dark gray (Bt), radiating from a larger crystal or criss-crossing and tiny grains of wustite (white) on dark aluminate. 
Figure 7 and Figure 8 show aluminate crystals of no definite shape, dark gray lenticular belite (Bt) crystals radiating from nuclei or from a larger belite crystal or criss-crossing (Figure 8). Figure 8 shows white dendritic wustite crystals (Wu) of no definite shape and direction and belite crystals (light to dark gray).

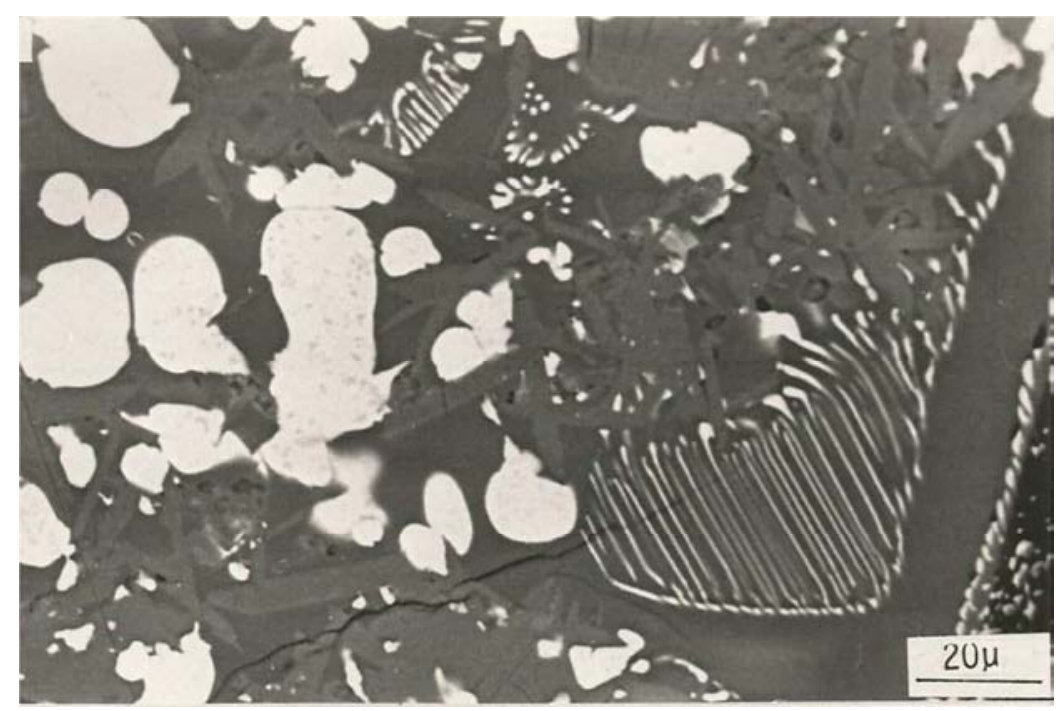

Figure 9. $(20 \mu$ ). Shows light gray to white fibrous wustite (Wu) in dark aluminate and wustie crystals of random orientation.

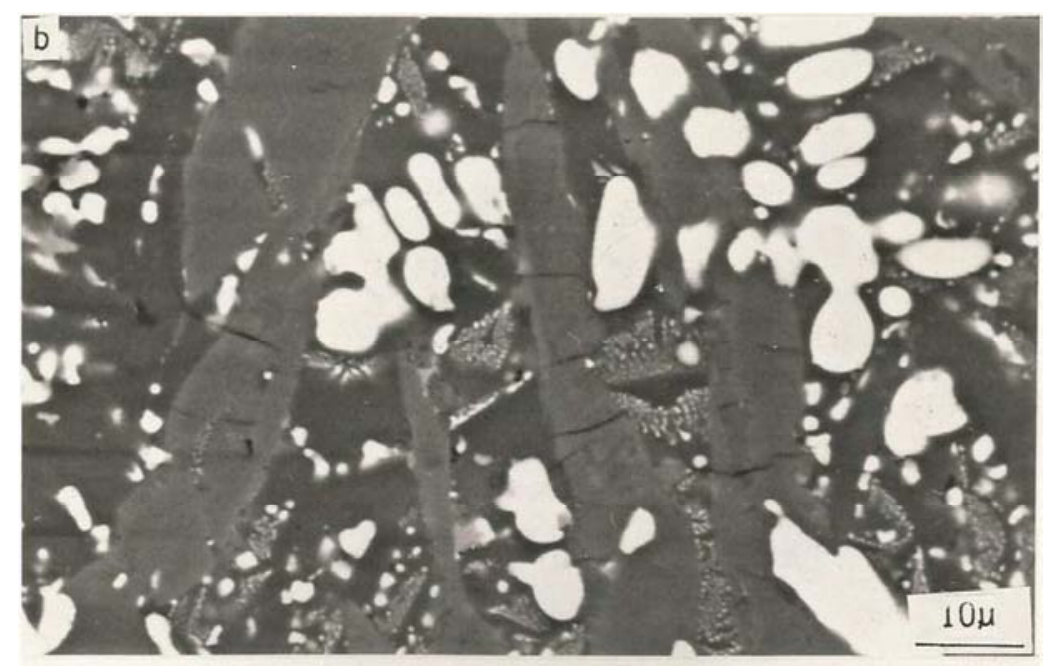

Figure 10. $(10 \mu)$. Shows radiant lenticular belite, wustite laths and round grains (white) in belite (gray) and aluminate (dark).

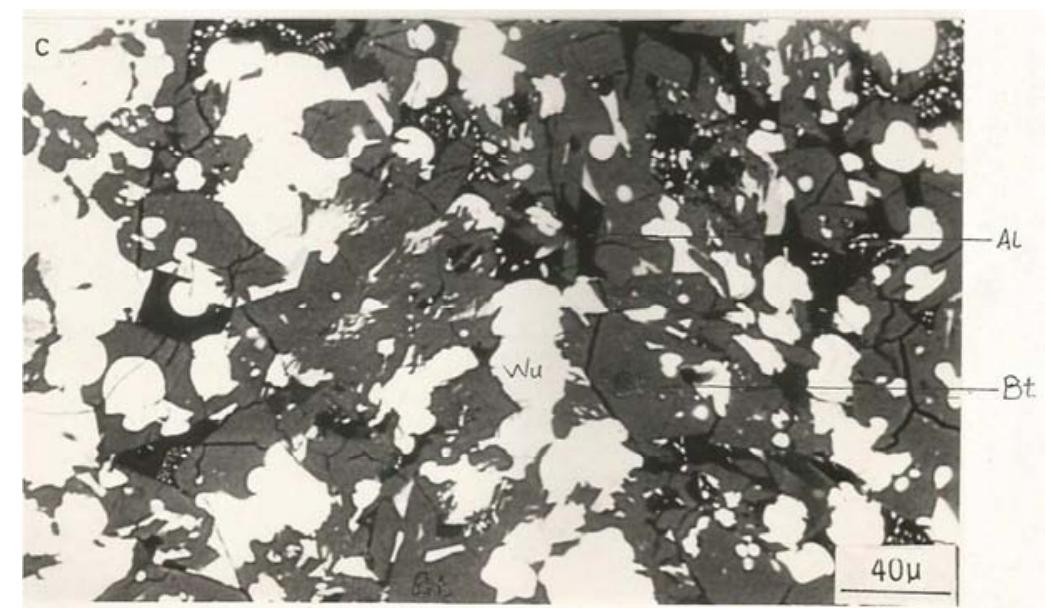

Figure 11. $(40 \mu)$. Shows intergrowth texture exhibited by DSC slag minerals (belites and wustites, prominently). 
Figure 9 shows fibrous wustite (light to dark gray) in dark aluminate and lenticular belite radiating from larger belite crystals or inter-crossing. Figure 10 shows the radiant belites, wustite laths and round grains (white) in belite (gray). Figure 11 shows the intergrowth texture exhibited by the DSC slag minerals, prominently by the belites and the wustites.

\section{Discussion}

DSC slag cooling process started from high temperatures and mineral crystallization starting at below $1500^{\circ} \mathrm{C}$ continuing to lower temperatures of about $500^{\circ} \mathrm{C}$ in the ladle and in the slag dump[20][44]). During the cooling, silicates of belite of different polymorphs, melilite, merwinite; and wustite, calcium aluminate, periclase, peruvskite and glass crystallize occurring in different forms as listed in Table 1. Figure 1, Figure 2, Figure 3... Figure 11, showed the back scattered mode scanning electron microscope (SEM) and the Ziess Ultraphot photomicrographs of polished thin sections. These depict the mineral phases that crystallized as the slag cooled and their occurrence was used to explain the possible sequence of crystallization.

\subsection{Mineral Material Occurrence}

Belite (brown or dark gray colour) in the beta form was present as large discrete crystals and as small crystal inclusions in wustite (white), (see Figure 1, Figure 4 and Figure 5). Some melilite (gehlenite $\left(2 \mathrm{CaO} . \mathrm{MgO} .2 \mathrm{Si}_{2}\right)$ coexisted with wustite $(\mathrm{Fe} 0)$ and calcium aluminate $\left(\mathrm{CaO} \cdot \mathrm{Al}_{2} \mathrm{O}_{3}\right.$ - $\mathrm{C}_{3} \mathrm{~A}$ ) as interstitial material (Figure 11). The melilite, merwinite, wustite and calcium aluminate also occurred enclosed in the belite and formed the glass (Figure 4 and Figure 5). Periclase grains occurred as euhedral or spherical shaped crystals with the cryptocrystalline wustite groundmass in certain areas and surrounded by thin shells of wustite in other areas (Figure 2 and Figure 3). Peruvskite occurred in association with belite and wustite but sometimes as rectangular and irregular light gray shades on wustite (Figure 11). Minor amounts of iron occurred as whitish rounded droplets. These may have formed from the immiscibility of the metal phase formed in the slag. The minor differences in slag sample chemical composition was reflected in the general similarity of the crystalline phases occurring in the slag samples.

\subsection{Tertiarydiagrams}

The Geochemical data of DSC slag have been plotted along with the relevant phase boundaries onto the various triangular systems of these oxides. Figure 12 shows the mineral equilibrium relations and crystallization sequence of the slag minerals. Accurate interpretation of the data from the comparison with these systems has not been possible. This is because the planes of the phase diagrams were fixed but the slag component minerals and glass did not lie exactly within any of these planes. The minor elements present in the slag (alkali, S, P) may also have had some effect on the phase chemistry.

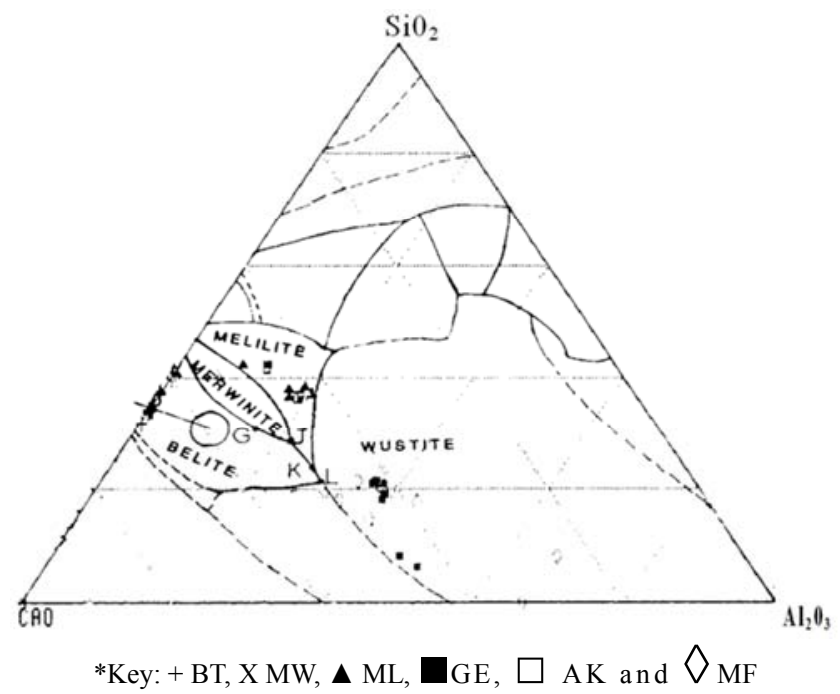

Figure 12. DSCslag bulk composition. Phase equilibrium relations of DSC slag minerals. The planethroughthe tetrahedron $\mathrm{CaO}-\mathrm{Al}_{2} \mathrm{O}_{3}-\mathrm{SiO}_{2}$ (modified from Prince, 1954) belite (BT); merwinite $(M W)$; melilite $(M L)$; gehlenite $(G L)$; akermanite $(A K)$; periclase $(M G)$; and wustite $(M F)$.

\subsection{Mineral Crystallization Sequence}

From the phase diagrams (Figure 1, Figure 2, Figure $3 . . . .$. Figure 13), it was possible to suggest that, at above $1500^{\circ} \mathrm{C}$ the slag was in liquid form in the furnace. Crystallization may have started below $1500^{\circ} \mathrm{C}$ as the slag started cooling in the slag ladle and in the dump. As cooling continued, it is likely that the $\alpha$-belite formed and remained stable at a temperature of above $1420^{\circ} \mathrm{C}$. With a temperature drop below $1420^{\circ} \mathrm{C}$ it changed to the $\alpha^{\prime}$-belite (alpha high) form which existed till $680^{\circ} \mathrm{C}$ when the beta-belite formed, began to crystallize. However, the presence of fractured belite crystals (Figure 1) suggest that some of the $\alpha$ - and $\alpha$ forms may have been stabilized between $1420^{\circ} \mathrm{C}$ and $680^{\circ} \mathrm{C}$ with faster cooling when water was sprayed on the slag to assist in cooling. The fracturing may have resulted from the inability of these higher temperature polymorphs to change to the lower temperature $\beta-C_{2} S$ and $\gamma-C_{2} S$ forms $\left(\gamma-C_{2} S\right.$ stable form was not detected). The occurrence of belite as large discrete crystals and as small crystal inclusions in wustite suggested that it was the first major solid phase to form in the slag. The crystallization must have started with the $\alpha-$ and $\alpha^{\prime}-$ forms between below $1500^{\circ} \mathrm{C}$ and $680^{\circ} \mathrm{C}$. This was a strong pointer that belite crystallization took place throughout the cooling process of the slag. The $\beta-\mathrm{C}_{2} \mathrm{~S}$ form may have started forming at $680^{\circ} \mathrm{C}$ and remained stable till $630^{\circ} \mathrm{C}$ below which, it could have started transforming into the gama-belite $\left(\gamma-\mathrm{C}_{2} \mathrm{~S}\right)$ form. The $\gamma$-form should exist at temperatures below $500^{\circ} \mathrm{C}$ (Figure 13). 


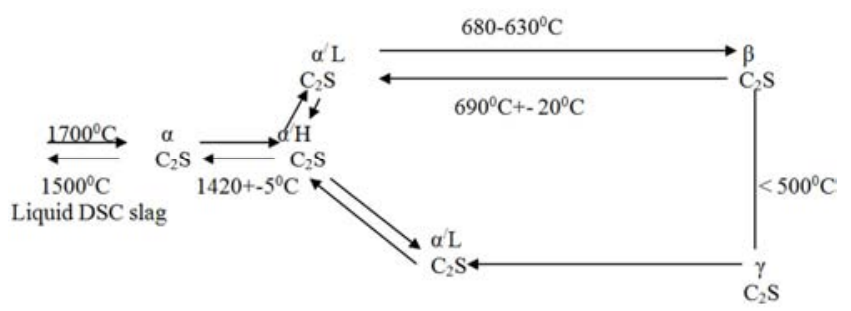

Figure 13. Schematic diagram of DSC slag high temperature (above $1400^{\circ} \mathrm{C}$ $\mathrm{C}_{2} \mathrm{~S}$ transformations to lower temperature $\left(500^{\circ} \mathrm{C}\right)$ polymorphs.

With an increase in temperature to $690^{\circ} \mathrm{C}$ from $630^{\circ} \mathrm{C}$, the $\beta-\mathrm{C}_{2} \mathrm{~S}$ could transform to the $\alpha^{\prime}-\mathrm{C}_{2} \mathrm{~S}$ form which might seem to be the plausible reason for the non detection of the $\gamma-\mathrm{C}_{2} \mathrm{~S}$. But the history of the slag has been that of a continuous cooling process and an increase in temperature may not have occurred and cannot account for the non detection of the $\gamma$ form. The presence of unstabilized $\beta-\mathrm{C}_{2} \mathrm{~S}$ (un-crosshatched) form suggested that some of the $\beta$-form of belite could have converted to the $\gamma$-form with a temperature fall. But the non detection of $\gamma$-form in the slag suggested that the $<500^{\circ} \mathrm{C}$ form forming temperature may not have been attained during the process of slag solidification. Most of the belite existed in the meta-stable beta form possibly between $680^{\circ} \mathrm{C}$ and about $630^{\circ} \mathrm{C}$.

From the results obtained, the belites of the slag can be classified into;-

Type 1. Belite crystals without twinning features which were dominantly $\alpha-C_{2} S$. Twinning traces were

observed in the $\alpha^{\prime}-\mathrm{C}_{2} \mathrm{~S}$ most probably transformed from the $\alpha-\mathrm{C}_{2} \mathrm{~S}$ indicating resulting from a less slow cooling.

Type 2. Belite crystals with wide distinctive lamellae with two or three orientations. These belite

crystals were $\alpha^{\prime}-\mathrm{C}_{2} \mathrm{~S}$ and stabilized $\beta-\mathrm{C}_{2} \mathrm{~S}$ from $\alpha^{\prime}-\mathrm{C}_{2} \mathrm{~S}$ inversion; and,

Type 3. Belite crystals with many fine indistinct lamellae and multiple orientation most dominantly

$\beta-\mathrm{C}_{2} \mathrm{~S}$, which is similar to clinkers from production kilns [16],[29].

The general trend observed (see Figure 1) was:

i. The coexistence of melilite with alpha belite

ii. The inclusion of melilites in beta belites

iii. The inclusion of wustite (more) in belite,

iv. The inclusion of belites in wustite,

v. The inclusion of aluminate, periclase and peruvskite in belites and wustites,

vi. The inclusion of some round grains and fibrous wustite in aluminate, and;

vii. Merwinite co-existing with aluminate and some glass.

This mode of mineral occurrence suggested that, these phases probably crystallized with the late stage beta belite phase at low temperatures before $630^{\circ} \mathrm{C}$ and down to about $500^{\circ} \mathrm{C}$, when there may have been complete mineral formation. The non detection of $\gamma-\mathrm{C}_{2} \mathrm{~S}$ form, confirmed this suggestion. It is a pointer that belite crystallization (excluding $\gamma-C_{2} S$ ) continued throughout the cooling process of the slag.

The occurrence of euhedral melilite crystals, sometimes enclosed in the larger beta-belite $\left(\beta-C_{2} S\right)$ crystals suggested that their crystallization started before beta belite crystallization. Their occurrence with the alpha belites, also suggested that their crystallization started probably simultaneously with alpha-belite between $1420^{\circ} \mathrm{C}$ and $680^{\circ} \mathrm{C}$. Their associated occurrence with beta belite indicates their possible simultaneous crystallization with $\beta-\mathrm{C}_{2} \mathrm{~S}$ at $680^{\circ} \mathrm{C}$.. The coexistence of some melilite (gehlenite $\left(2 \mathrm{CaOMgO} 2 \mathrm{SiO}_{2}\right)$ with wustite $(\mathrm{Fe} 0)$ and calcium aluminate $\left(\mathrm{CaOAl}_{2} \mathrm{O}_{3}-\mathrm{C}_{3} \mathrm{~A}\right)$ as interstitial material indicated a late stage crystallization confirming that melilite crystallization continued till slag final solidification. This late stage crystallization likely between $630^{\circ} \mathrm{C}$ and $500^{\circ} \mathrm{C}$ was confirmed by SEM and EMPA identified occurence of melilite, merwinite, wustite, aluminate and glass as interstitial material.

Periclase occurred with cryptocrystalline wustite groundmass in certain regions and surrounded by thin shells of wustite in other areas. This later situation indicated that they may have crystallized before wustite, but the euhedral or spherical shapes of the periclase grains suggest that periclase, resulted from a higher surface free energy for periclase during its crystallization together with wustite.

Perovskite occurred in association with belite and wustite. It sometimes occurred enclosed in the wustite and sometimes as rectangular and irregular light grey shades on wustite. The enclosed occurrence indicated that the perovskite crystallized before the wustite, the associated occurrence indicated the crystallization together with late stage belite but, after the wustite. The occurrence as light grey shades indicated that the peruvskite crystallized after the wustite possibly, squeezed out of the belite.

\subsection{Summary of Mechanism of Mineral Formation}

The mechanism of mineral formation in the slag cannot be fully explained here, but the indication is that formation may have taken place between above $1420^{\circ} \mathrm{C}$ and $500^{\circ} \mathrm{C}$. From the foregoing, the most probable mineral crystallization sequence in the Slag can be summarized as thus:-

a $\mathrm{C}_{2} \mathrm{~S}$

b $\mathrm{C}_{2} \mathrm{~S}+$ Melilite

c $\mathrm{C}_{2} \mathrm{~S}+$ Melilite + Merwinite

d $\mathrm{C}_{2} \mathrm{~S}+$ Melilite + Merwinite + Wustite $+\mathrm{C}_{3} \mathrm{~A}$

e $\mathrm{C}_{2} \mathrm{~S}+$ Melilite+Merwinite+Wustite + Periclase + Peruvskite

This order of crystallization sequence suggested, can be seen from the occurrence of discrete crystals of the various phases and the inter-face relations- inclusions and interfingering co-existence. The crystallization can be explained using Figures 1, Figure 2, Figure 3.......... Figure 13).

Figure 13 shows the form of mineral crystallization. It depicts that $\mathrm{C}_{2} \mathrm{~S}$ was the first phase to start crystallizing as cooling started till point $\mathrm{G}$ when merwinite may have started crystallization. Both phases continued crystallizing till the triple point $\mathrm{J}$, where they co-existed with melilite which may have started crystallizing at an earlier stage. As cooling continued to point $\mathrm{K}, \mathrm{C}_{2} \mathrm{~S}$, melilite, wustite and possibly $\mathrm{C}_{3} \mathrm{~A}$ co-existed having crystallized from a liquid depleted of 
merwinite, which may have completed crystallization. This seems to confirm the conclusion that wustite and periclase were the last phases to crystallize whilst $\mathrm{C}_{2} \mathrm{~S}$ crystallization continued throughout the slag cooling process.

\section{Mineral Phase Potential Material Use in Industry}

Recent chemical and mineralogical investigation of steelmaking slags has resulted in their applications as industrial materials in construction and building, ceramics, cement, glass and agriculture [9]. Electron microprobe analyses results of DSC slag indicate the richness of the mineral phases in major steelmaking elements from belite, melilite and merwinite silicates, wustites, periclase and perovskite in terms of $\mathrm{Si}, \mathrm{Ca}, \mathrm{Fe}, \mathrm{Mg}$, and $\mathrm{Ti}$ [41]. These elements in the slag are required for the blast furnace iron and steel making process [12], [24], [26], [37], slag ceramics [25], slag cement [26], [27], [31], [32], [33], [35] and agriculture [3]. $\mathrm{CaO}$ can be a fluxing and mineral forming agent in reaction with unwanted elements from the iron making ingots.

The silicates can be major sources, of $\mathrm{Si}, \mathrm{Ca}$ and $\mathrm{Fe}$ necessary for use in iron and steelmaking blastfurnace as feed and in the agricultural industry as fertilizer [3]. Belite in the slag had hydration properties as shown by the presence of beta-belite and therefore suitable for slag cement manufacture [1], [2], [41]. The silicates and peruvskite can provide agriculture important phosphorus $(\mathrm{P})$, possibly for direct application or used to produce phosphate fertilizer.

Peruvskite contained a good proportion of $\mathrm{Ca}$ and can be combined with the silicates for use as fertilizer. Wustite, as a major source of Fe can be used as blastfurnace feed, and as fertilizer, combined with peruvskite. It can also provide some $\mathrm{MnO} / \mathrm{Mn}$, suitable for use in the iron and steelmaking blastfurnace. Periclase and wustite can be the major sources of $\mathrm{MgO} / \mathrm{Mg}$ suitable for use as fertilizer in the agriculture and slag ceramics industry. These mineral phases in DSC slag can be separated using standard mineral separation methods for use in different industries.

\section{Conclusion}

Mineral crystallization in the slag started at high temperatures of about $1420^{\circ} \mathrm{C}$ continued till low temperatures of about $500^{\circ} \mathrm{C}$ when the slag completely solidified. Melilites and the alpha belites formed between $1420^{\circ} \mathrm{C}$ and $680^{\circ} \mathrm{C}$. At a late stage crystalization between $680^{\circ} \mathrm{C}$ and $500^{\circ} \mathrm{C}$ there was continuous crystallization of all minerals except the alpha belites till the final solidification of the slag. This crystallization of slag minerals from the cooling of the slag clinker at high temperatures to low temperatures was similar to that of cement clinkers and that of natural minerals from igneous magma. From the temperatures of existence the different mineral phases can be separated for different material uses. For example the meta stable beta belte $\left(\beta-\mathrm{C}_{2} \mathrm{~S}\right)$ the phase that provides hydraulic property can be separated between $680^{\circ} \mathrm{C}$ and $630^{\circ} \mathrm{C}$ for use as a cement, slag cement, slag ceramics, agriculture and civil engineering material.

\section{References}

[1] Atwell J. S. F. (1974). Some properties of ground granulated slag and cement, In Proceedings Institution of Civil Engineering vol. 57 part 2, June, pp. 233-250.

[2] Barnes, P., Jeffery, J. W. and Sarkar, S. L., (1972). Composition of Portland cement belites, Cement and Concrete Research. 18, pp. 559-564.

[3] Branca, T. A. \& Colla, V., (2012). Possible uses of Steelmaking Slag in Agriculture: An Overview, Intech, Scuola Superiore Sant'Anna - PERCRO - TeCIP Institute, Italy.

[4] Das, B, Prakash, S, Reddy, P. S. R, and Misra, V. M., (2007). An overview of utilization of slag and Sludge from steel industries, Resources, Conservation and Recycling, vol. 50, no. 1 , pp. $40-57$.

[5] Dunham, A. C. and Wilkinson F. C. F., (1976). Accuracy, Precision and Detection Limits of Energy-Dispersive ElectroMicroprobe Analysis and Silicates.

[6] Delta Steel Company, (DSC), (1985). Internal documentary on steelmaking process.

[7] Emery, J. J. (1977). Slags as Industrial Minerals, $3^{\text {rd }}$ Industrial Minerals International Congress pp.127-142.

[8] Fletcher, K. E., (1968). The analysis of the belite in Portland cement clinker by means of an electron-probe microanalyser, Magazine of Concrete Research., 20, 64, pp.167-170.

[9] Geiseler, J., (1994). Steel slag-generation, processing and utilization, In Proceedings of the International Symposium on Resource Conservation and Environmental Technologies in Metallurgical Industry, pp. 87-97, Toronto, Canada, August.

[10] Ghose, A \& Barnes, P (1979). Electron microprobe analysis of Portland cement clinker, Cement and_Concrete Research, 9, 6, pp.747-755.

[11] Gutt, W \& Nurse, R, W., (1974). The phase composition of Portland cement clinker, Current paper 96/74, Build. Research Establishment Watford, U. K.

[12] Joseph, R. W. and Haddad, M., (1975). Utilization of Steelmaking Slags in blast furnace burdens, Open hearth proceedings $58^{\text {th }}$. The Metallurgical Society of AIME. Shelf No 6848, 093 vol. 58 pp. 140-159.

[13] Juckes, L. M., (2003). The volume stability of modern steelmaking slags, Mineral Processing and Extractive Metallurgy, vol. 112, no. 3, pp. 177-179.

[14] Kristmann, M., (1977). Portland cement clinker mineralogical and chemical investigation (Part 1 and II). Cement and Concrete Research 7, pp. 649-658.

[15] Maki, I., (1973). Microscopy of cement, Cement and Concrete Research, 3, 295.

[16] Medland J., (1983). Portland cement clinkers, Unpublished $\mathrm{Ph}$. D. Thesis, University of Hull. 
[17] Midgley, H. G., (1974). The polymorphism of calcium orthosilicate, In Proceedings Vth. International Symposium, Chemistry of Cement (Mosco) Part 1.

[18] Monaco, A. \& Lu, W. K., (1994). The cooling effect of cooling conditions on the mineralogical characterization of steel slag, The Canadian Institute of Mining, Metallurgy and Petroleum, In Resource conservation and environmental technologies in metallurgical industries, pp. 107-118.

[19] Moore, A. E., (1965). Examination of a Portland cement clinker by electron probe micro-analysis. Silicate Industries. 30,8 , pp. $445-450$.

[20] Nurse, R. W., (1952). The dicaclucium silicate phase, In Proceedings. IIIrd. International Symposium, Chemistry of cement, (London), pp. 56-77.

[21] Nurse, R. W., (1960) Phase equilibra and constitution of Portland cement clinker. Proc. IVth. Inter. Symposium. Chemistry of Cement (Washington), National Bureau of Standards (U.S.A.), pp. 9-37.

[22] Piatak, N. M. Parsons, M. B. Seal, R. R, (2015). Characteristics and Environment aspects of iron and steelmaking slags, Applied Geochemistry, Elsevier.

[23] Pugh, J. L. and Fletcher, L. N., (1974). Basic Oxygen Furnace slag as a Blast Furnace material, AIME Ironmaking Proceedings. vol. 32 pp. 374-375.

[24] Qian, G. R, Sun, D. D, Tay, J. H and Z. Y. Lai, Z. Y., (2002) Hydrothermal reaction and autoclave stability of $\mathrm{Mg}$ bearing RO phase in steel slag, British Ceramic Transactions, vol. 101, no. 4, pp. 159-164.

[25] Ray, H. S., Kanpur, B. S. and Lal, A., (1974). Note on a slagceramic, Journal of the Institution of Engineers (India), Mining and Metallurgy Division. Vol. 54 part MN3, July, pp. $69-71$

[26] Reddy, A. S, Pradhan, R. K, and Chandra, S., (2006). Utilization of Basic Oxygen Furnace (BOF) slag in the production of a hydraulic cement binder, International Journal of Mineral Processing, vol. 79, no. 2, pp. 98-105.

[27] Regourd, M. and Guinier, A., (1974). The crystal chemistry of the constituents of Portland cement clinker, In Proeedings VIth. International Symposium, Chemistry of Cement, vol. 1 (Moscow), pp. 25-52.

[28] Sarka, S. L., (1977). Dicalcium Silicate, Ph. D. Thesis, University of London.

[29] Scott, P. W, Crittchley, S. R. and Wilkinson, F. C. F., (1986). The chemistry and mineralogy of some granulated and pelletized blast furnace slags, Mineralogical Magazine, vol. 50, pp. 141-7.

[30] Shi, C., (2002). Characteristics and cementitious properties of ladle slag fines from steel Production, Cement and Concrete Research, vol. 32, no. 3, pp. 459-462.

[31] Shi, C., (2004). Steel slag-its production, processing, characteristics, and cementitious properties, Journal of Materials in Civil Engineering, vol. 16, no. 3, pp. 230-236.

[32] Spellman, I. U., (1980). New generations of slag cement show promise Rock Products, vol. 10, pp. 141-7.

[33] Tossavainen, M., Engstrom, F., Yang, Q., Menad, N., Larsson, M. L. and Bjorkman, B., (2007). Characteristics od steel slag under differwent cooling conditions, Waste Management, vol. 27 , no. 10 , pp. $1335-1344$

[34] Tsakiridis P. E, Papadimitriou, G. D, Tsivilis, S, and Koroneos, C., (2008). Utilization of steel slag for Portland cement clinker production, Journal of Hazardous Materials, vol. 152 , no. 2 , pp. $805-811$.

[35] Thilo, E. and Funk, H., (1959. Effects of small amounts of alkalis on the $\beta-\gamma$ inversion in $\mathrm{C}_{2} \mathrm{~S}$.., Z_Anorg. Allgem. Chem., 273, pp.1-2, 28-40.

[36] Thom, G. G. W. and Wood, J. K., (1973). Steelmaking slag -A blast furnace feed. AIME Ironmaking Proceedings, vol. 32, pp. 363-362.

[37] Tossavainen, M. Engstrom, F. Yang, Q. Menad, N. Larsson, M. L. and Bjorkman, B., (2007). Characteristics of steel slag under different cooling conditions, Waste Management, vol. 27 , no. 10 , pp. $1335-1344$.

[38] Waligora, J, Bulteel, D, Degrugilliers, Damidot, D, Potdevin, J. L., and Measson, M., (2010). Chemical and mineralogical characterizations of LD converter steel slags: a multianalytical techniques approach, Materials Characterization, vol. 61 , no. 1 , pp. $39-48$.

[39] Welch. J. H. and Gutt. W., (1960). The effect of minor components on the hydraulicity of calcium Silicates, In Proceedings, IVth. International Symposium, Chemistry of Cement (Washinton)., pp. 56- 68.

[40] Wessey, N., (1988). Evaluation of the Industrial Potential of Nigeria Direct Reduction Steelmaking Slag, Ph. D. Thesis, University of Hull, 316pp.

[41] Yamaguchi, G. and Takagi, S., (1968). The analysis of Portland cement clinker, In Proceedings, Vth. International Symposium, Chemistry of Cement (Tokyo), Part 1, pp. 181225.

[42] Yannaquis, N \& Guinier, A., (1959). Polymorphic $\beta-\gamma$ transition of calcium orthosilicate. Bulletin Society, France, Mineral Cristallization, 82, pp.126-136.

[43] Yildirim, IZ \& Prezzi, M., (2011). Chemical, Mineralogical, and Morphological Properties of Steel Slag, Creative Commons Attribution License. 